\title{
Help-Seeking in an Academic Context: A Systematic Review
}

\author{
Sergi Martín-Arbós (D), Elena Castarlenas and Jorge-Manuel Dueñas *(D) \\ Department of Psychology, Area of Developmental and Educational Psychology, Universitat Rovira i Virgili, \\ 43007 Tarragona, Spain; sergi.martin@urv.cat (S.M.-A.); elena.castarlenas@urv.cat (E.C.) \\ * Correspondence: jorgemanuel.duenas@urv.cat
}

\begin{abstract}
Academic help-seeking as a learning strategy can influence academic achievement. Indeed, seeking help when needed is considered a self-regulated learning strategy that should be taken into account from the educational perspective. In this study, we review twenty-five articles published over the last 10 years that have analysed academic help-seeking in adolescents or university students. The aims of this review are to describe the relationship between academic help-seeking and other sociodemographic, educational, and psychosocial variables, and to evaluate the instruments that are used to assess academic help-seeking. Our results show that there is a lack of consensus on the structure of help-seeking as a construct. Moreover, the role of sex and age is unclear, and there is little replication in the correlational models. Further research is needed to better define the construct and compare the variables that influence academic help-seeking at different stages of education.
\end{abstract}

Keywords: academic help-seeking; high school; university students; college students; help

Citation: Martín-Arbós, S.;

Castarlenas, E.; Dueñas, J.-M.

Help-Seeking in an Academic Context: A Systematic Review.

Sustainability 2021, 13, 4460.

https://doi.org/10.3390/su13084460

Academic Editor: Susana Rodríguez Martínez

Received: 15 March 2021

Accepted: 14 April 2021

Published: 16 April 2021

Publisher's Note: MDPI stays neutral with regard to jurisdictional claims in published maps and institutional affiliations.

\section{Introduction}

Students may face difficulties in completing their assignments and may need assistance in their education. Academic help-seeking (AHS) involves seeking support from individuals and other sources to help students to achieve good results in an academic context $[1,2]$. It has been defined from a self-regulated learning perspective as a social strategy, since it involves classmates, teachers, and parents [3,4]. A help-seeking strategy plays an important role in learning because it can affect academic achievement in a relatively short time span [5]. Help-seeking sources are diverse, but in the academic context, the most common ones are peers, teachers and, more recently, the Internet, which is now an important tool for reaching experts or finding specific knowledge [6,7]. Two forms of help-seeking have been proposed [1,2,8,9]: executive help-seeking and instrumental help-seeking. Executive (also called expedient) help-seeking occurs when students wish to have the task solved for them, while instrumental (or adaptive) help-seeking occurs when students request only the amount of help they need to complete the task on their own. With the spread of new technologies, a new form of academic help-seeking has been proposed. Students can now seek online assistance, and this type of help can be provided by experts or by a help system [10]. In addition, information searching is proposed as a specific type of help-seeking $[6,10]$.

Self-regulated learning (SRL) is a construct proposing that the student is an active participant of his or her own learning process and involves metacognition, motivation, and behaviour, including variables such as planning, self-efficacy, verbal self-instruction, or seeking assistance [11]. This model includes three cyclical phases: (1) Fore-thought, when the student prepares themselves to learn; (2) performance, when the learning session is taking place and the student tries to control and observe their performance; and (3) self-reflection, when the effort to learn is done and the student evaluates the outcomes. The evaluation of the third phase will influence the forethought phase of the next learning sessions [11].

Several models of the help-seeking process described in the literature $[2,12,13]$ can be associated with the self-regulation model by Zimmerman [14]. One of the most recent 
models was proposed by Karabenick and Berger [1], who established eight stages of the AHS process: (1) Determine whether there is a problem; (2) determine whether help is needed/wanted; (3) decide whether to seek help; (4) decide on the type of help; (5) decide whom to ask; (6) request help; (7) obtain help; and (8) process the help received (evaluating and reacting). These stages fit into the phases of forethought, performance, and self-reflection described by Zimmerman [14] and mentioned above. Help-seeking always requires another individual to provide the assistance, but the decisions about whether to ask for help and what kind of help to ask for are made by the student according to their assessment of the situation.

The cognitive and motivational components of help-seeking mean that attitudes to help-seeking can play a crucial role in that behaviour [15]. The perceived benefits of helpseeking include performing better on tasks and achieving personal learning goals. The perceived costs, on the other hand, include being regarded as less competent than one's peers or feeling too embarrassed to ask for help, which may cause students to avoid asking for help when they need it $[4,13,15,16]$. According to Butler [9], three situations explain the avoidance of help-seeking: The autonomous, for example, when students try to be independent when completing their assignments; the ability-focused, when they try to hide their incompetence; and the expedient, when they believe asking for help will not get the task done. According to Newman [17], there may be cultural differences when it comes to help-seeking, as certain attitudes or the value of each help-seeking component may depend on the culture of those involved. In light of the above, academic help-seeking is relevant to the learning process, and the variables associated with this strategy among adolescents and university students should be thoroughly understood.

\section{The Current Review}

Since the 1980s, a significant number of studies have been published that dive deeper into the definition of academic help-seeking as a construct and its structure $[2,4,8,18,19]$, linking it with other essential variables in the educational field $[4,9,16,17,20,21]$. Throughout the past ten years, the interest in this construct has increased [22]. Nonetheless, no systematic review to our knowledge has been conducted so far, which makes it necessary for our study to compare the previous research results. This review can be a helpful resource for future researchers and allow them to plan their investigation better. Our research questions are: (1) What are the new contributions in the field of AHS?; (2) what variables are associated with AHS in adolescents and university students; and (3) which instruments are used most in evaluating the AHS construct? Based on these questions, the objectives of this review are: (1) To summarize the knowledge produced over the last ten years on academic help-seeking in adolescents and university students; (2) to describe the variables associated with academic help-seeking and the nature of this relationship; and (3) to identify the most common instruments used to evaluate academic help-seeking.

\section{Methods}

\subsection{Search Strategy and Selection Criteria}

Our procedure for this systematic review was designed in accordance with the PRISMA statements. This helpful resource improves the reporting of results for systematic reviews and meta-analyses $[23,24]$.

We conducted a literature search for articles published between January 2010 and July 2020 in the following databases: Web of Science, Scopus, PsycNet, ERIC, and Psicodoc. The keywords we used in the search engines were: Help seeking OR help-seeking AND (academic OR education* OR scho* OR college OR university) in the abstract. We did not use filters by author, journal type, country, funding source, journal title, age, or editor. When possible, we filtered by language (English, Catalan, or Spanish), subject area (education or educational psychology), and document type (including only articles). Not all filters were available in all databases. Reference lists of selected articles were checked to identify additional studies of interest. 
The criteria established by the researchers were as follows: (1) The articles must have been published in indexed peer reviewed journals; (2) the main topic had to be academic help-seeking; (3) the sample had to be made up of students aged over 12 (mainly adolescents and university students); and (4) the data had to be obtained directly from participants via self-reports. We excluded qualitative studies, articles seeking to adapt or validate instruments, articles using ad hoc instruments, reviews or meta-analyses, and (to avoid type-2 errors) articles with less than 55 participants.

\subsection{Data Extracion}

As the PRISMA flow chart in Figure 1 shows, our first search identified 3492 potentially eligible articles. After eliminating duplicate references, we kept 3314 of them, which we then screened for eligibility based on the article's title and abstract. Most of these articles $(\mathrm{N}=3030)$ involved help-seeking in non-academic contexts (e.g., seeking psychological help for clinical problems from books or the Internet or help in relation to human resources), were published in languages that were not considered in this review, or were not indexed articles. At this point, we had 264 valid references.

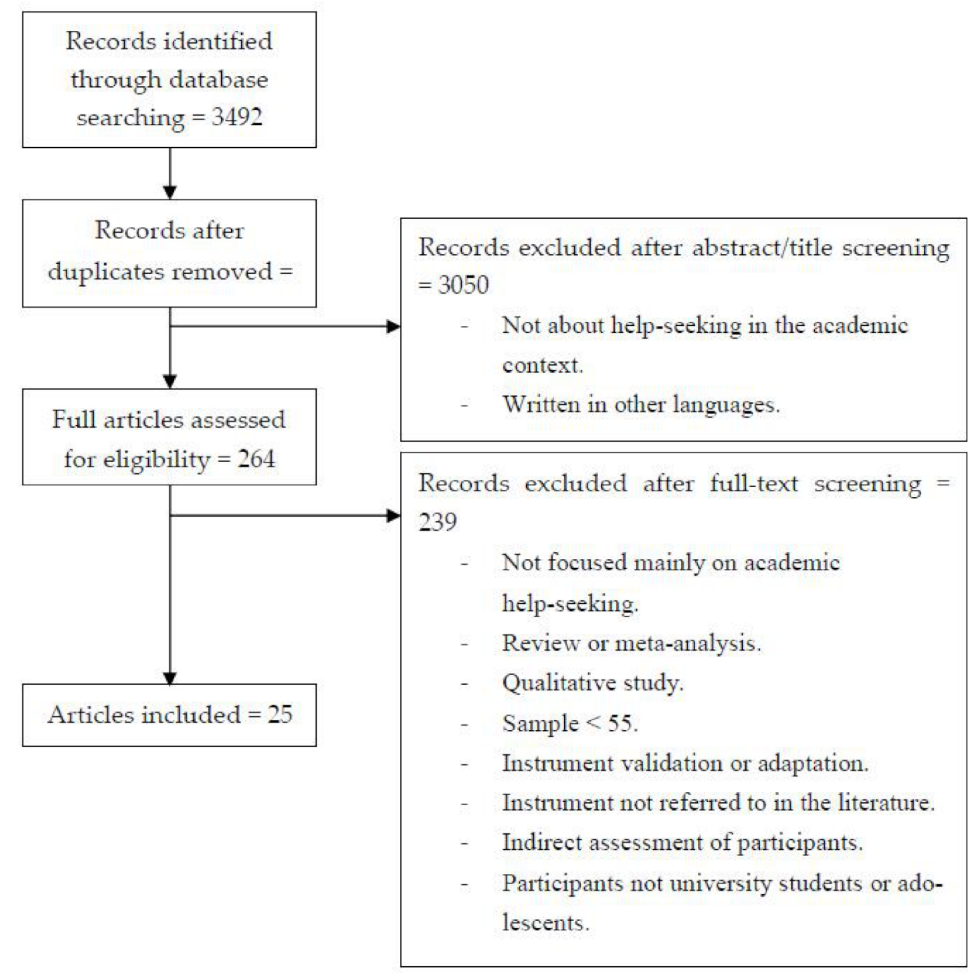

Figure 1. PRISMA flow chart of our selection procedure.

After full-text screening, 239 references were discarded because they did not satisfy the inclusion criteria. Ultimately, twenty-five references were included in our review, Figure 1 shows our procedure for selecting the articles used in this study.

\subsection{Quality Review}

We conducted a quality assessment of the 25 papers included in this review. To do so, we adapted the framework developed by Caldwell et al. [25] and rated every item from 0 to 2 (see Table 1). Specifically, we gave a score of 2 when the criterion was entirely satisfied, a score of 1 when it was partially satisfied, and a score of 0 when the criterion was not satisfied or was missing. Rather than using a score of 0 as an exclusion criterion, we followed the same procedure as Surr et al. [26], who rated the quality of the articles according to the items described, and divided them into three groups according to their total score, i.e., high quality (27-34), medium quality (14-26), and low quality (0-13). 
Table 1. Criteria used to assess the quality of the studies included in this review (adapted from Caldwell et al. [25]).

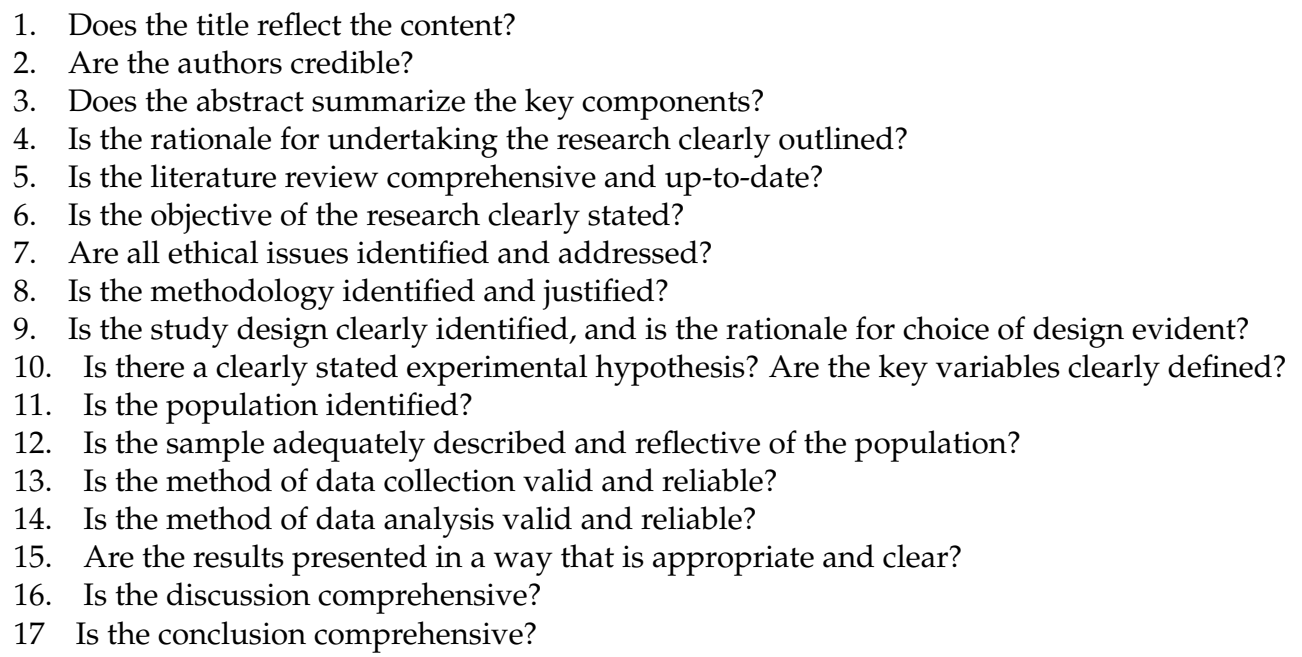

Articles rated 'high quality' matched most quality criteria to an acceptable degree and their results can be trusted to a greater extent. Those rated 'low quality' matched fewer quality criteria and their findings should be treated with caution. For the present review, we rated each study separately, compared scores, and discussed any disagreements until consensus was reached.

\section{Results}

\subsection{Quality Assessment of the Articles}

As required for the review, all the studies were published in peer-reviewed journals indexed in electronic databases. Specifically, 23 of the 25 articles included were published in indexed journals in SCOPUS, 19 in Web of Science, and 2 articles were indexed in ERIC. In addition, 19 (76\%) of the 25 articles included in this review were given a total score of $\geq 27$ and were rated "high quality" according to the quality assessment guideline described in the method section. The total scores of the six $(24 \%)$ remaining studies ranged from 14 to 27, thus indicating "medium quality". No article scored in the low range. The scores ranged from 23 to 32 and averaged $28.44(\sigma=2.71)$.

\subsection{Instruments for Assessing Academic Help-seeking}

Twenty different instruments were used to assess help-seeking in the articles we reviewed. Most studies used only one instrument to assess this construct but two studies used two instruments. The instruments used in each study are shown in Tables 2 and 3. The most common instrument was the Motivated Strategies for Learning Questionnaire (MSLQ) by Pintrich et al. [27], which appeared in four articles, followed by the Online Academic Helpseeking Questionnaire (OAHS) by Cheng and Tsai [6], which appeared in three articles. With eight citations, the most-cited author in relation to help-seeking assessment instruments was Karabenick.

\subsection{Academic Help-Seeking as a Construct}

Before presenting our results, we should emphasize that the lack of consensus when it comes to defining the construct and its components and determining how to evaluate those components makes it difficult to establish robust and valid conclusions. Studies often do not assess every component of AHS described in the literature. For example, three studies in our review assessed just one component, i.e., help-seeking avoidance [28-30]. Moreover, those that assessed a wider range of components also differed in relation to which and how many components were assessed. 
With regard to the stability of the construct, Schenke et al. [31] found that the scores on instrumental help-seeking, expedient help-seeking, help-seeking from peers, and helpseeking from teachers were relatively stable when measured at two time periods. Micari and Calkins [32] also assessed academic help-seeking at two different time periods and also found a correlation between the two scores.

\subsection{Academic Help-Seeking and Its Association with Psycho-Educational Variables}

\subsubsection{Results for Adolescent Students}

Ten of the articles included in the review, whose samples ranged from 180 to 3897 participants, examined help-seeking in adolescents. In this section, we present the relationships we observed between academic help-seeking and sociodemographic (e.g., age and gender), educational (e.g., achievement goals, self-regulation, and academic outcome), and psychosocial (e.g., perfectionism, friendship goals, and social goals) variables. More detailed information is provided in Table 2.

\section{Socio-Demographic Variables}

With regard to the age of students, Schenke et al. [31] found that high school students reported higher levels of instrumental help-seeking and help-seeking from peers than middle school students. They also reported gender differences, e.g., adolescent boys showed less instrumental help-seeking and less help-seeking from teachers and peers, but more expedient help-seeking than adolescent girls. Roussel et al. [33] also found that adolescent girls reported higher scores on instrumental help-seeking. These results are in agreement with those of the study by Kiefer and Shim [28], which reported that boys reported less adaptive help-seeking than girls. The same article also described a gender-by-time interaction for expedient help-seeking, with boys reporting more of this form of help-seeking only at one of the two time periods. Kessels and Steinmayr [34] reported a gender effect on students' intention to seek help, their intention to avoid help, the perceived costs of help-seeking, and expedient help-seeking, but reported no differences in instrumental help-seeking or the perceived benefits of help-seeking. According to Butler and Shibaz [35], girls showed greater intention to seek help than boys, which is in line with previous research. Kessels and Steinmayr [34], for their part, analysed gender role self-concept as a variable that may influence help-seeking. Although the correlations in their study were not significant enough in relation to the effect on help-seeking, they did observe a relationship between negative masculinity and school performance.

\section{Educational Variables}

Some studies focused on the perceived costs and benefits of help-seeking in the academic context. Roussel et al. [33], for example, found a significant negative association between the perceived costs of help-seeking and the perceived benefits of both help-seeking and instrumental help-seeking, as well as a positive association between the perceived benefits of help-seeking and instrumental help-seeking. Moreover, according to Gonida et al. [36], instrumental academic help-seeking could be predicted by the perceived benefits of help-seeking. Their study also included general intention to seek academic help, which was observed to be positively related to instrumental help-seeking and the perceived benefits of help-seeking, and to be negatively related to the perceived costs of help-seeking and help-seeking avoidance. Parker et al. [37] also found the same associations between adaptive help-seeking, perceived threats, and the perceived benefits of help-seeking.

Schenke et al. [31] found that instrumental help-seeking was related to help-seeking from teachers and help-seeking from peers at two time periods, while expedient helpseeking was unrelated or negatively related to them. Similarly, when Kiefer and Shim [28] studied help-seeking from peers, they found a significant positive relationship between avoidance of help-seeking and expedient help-seeking, but a significant negative relationship between those variables and adaptive help-seeking. In contrast, Kessels and Steinmayr [34] found no relationships among help-seeking variables. A different approach 
to help-seeking was used by Cheng et al. [38] and Lee et al. [39] in studies from an online perspective. Their results indicated that the three forms of help-seeking they studied (information searching, formal query, and informal query) were related, and that the relationship was stronger between informal query and the other two aspects.

Table 2. Characteristics, measures, and key findings from studies on adolescents students.

\begin{tabular}{|c|c|c|c|}
\hline Author and Year & Sample & AHS measure & Results \\
\hline $\begin{array}{l}\text { Roussel, Elliot and } \\
\text { Feltman (2011) }\end{array}$ & $\begin{array}{l}\text { Study 1: } N=317 \text { adolescents. } \\
\text { Study } 2: \mathrm{N}=234 \text { adolescents. }\end{array}$ & $\begin{array}{c}\text { Help-seeking Questionnaire } \\
\text { (HSQ) and Attitudes Toward } \\
\text { Help-Seeking Questionnaire } \\
\text { (ATHSQ) [4]. }\end{array}$ & $\begin{array}{l}\text { S1: Achievement goals predict } \\
\text { instrumental AHS. Women show more } \\
\text { instrumental AHS. } \\
\text { S2: Achievement goals also predict } \\
\text { perceived benefits of AHS and } \\
\text { perceived costs of AHS. }\end{array}$ \\
\hline $\begin{array}{l}\text { Cheng, Liang and } \\
\text { Tsai (2013) }\end{array}$ & $\mathrm{N}=319$ adolescents. & $\begin{array}{c}\text { Online Academic } \\
\text { Help-seeking questionnaire } \\
\text { (OAHS) [6]. }\end{array}$ & $\begin{array}{l}\text { OAHS scales are related to } \\
\text { internet-specific epistemic beliefs and } \\
\text { self-regulation. }\end{array}$ \\
\hline $\begin{array}{l}\text { Kessels and } \\
\text { Steinmayr (2013) }\end{array}$ & $\mathrm{N}=180$ adolescents. & Help-seeking Scale [40]. & $\begin{array}{l}\text { Academic outcome is predicted by } \\
\text { perceived benefits of AHS and } \\
\text { instrumental AHS. }\end{array}$ \\
\hline $\begin{array}{l}\text { Butler and Shibaz, } \\
\qquad 2014\end{array}$ & $\mathrm{~N}=1280$ adolescents. & $\begin{array}{l}\text { Hebrew Help-seeking Scale } \\
{[41] .}\end{array}$ & $\begin{array}{l}\text { Female adolescents show more AHS. } \\
\text { Teacher relational goals are related to } \\
\text { student AHS. }\end{array}$ \\
\hline $\begin{array}{l}\text { Lee, Chiu, Liang and } \\
\text { Tsai (2014) }\end{array}$ & $\mathrm{N}=342$ adolescents. & $\begin{array}{c}\text { Online Academic } \\
\text { Help-seeking questionnaire } \\
\text { (OAHS) [6]. }\end{array}$ & $\begin{array}{c}\text { OAHS scales are related to } \\
\text { internet-specific epistemic beliefs. } \\
\text { Adolescents show more help-seeking } \\
\text { behaviour with peers rather than } \\
\text { instructors. }\end{array}$ \\
\hline $\begin{array}{l}\text { Schenke, Lam, } \\
\text { Conley, and } \\
\text { Karabenick (2015) }\end{array}$ & $\mathrm{N}=3897$ adolescents. & Help-seeking Scale [8]. & $\begin{array}{l}\text { Help-seeking is related to adaptive } \\
\text { learning, emotional support and } \\
\text { variables of class climate. Help-seeking } \\
\text { is relatively stable. }\end{array}$ \\
\hline $\begin{array}{l}\text { Kiefer and Shim } \\
\qquad(2016)\end{array}$ & $\mathrm{N}=345$ adolescents. & $\begin{array}{c}\text { Help-seeking Scales } \\
{[15,42-44]}\end{array}$ & $\begin{array}{l}\text { Help-seeking is related with social } \\
\text { goals, adaptive learning, and teacher } \\
\text { emotional and academic support. }\end{array}$ \\
\hline $\begin{array}{l}\text { Gonida, Karabenick, } \\
\text { Stamovlasis, } \\
\text { Metallidou, and CTY } \\
\text { Greece (2019) }\end{array}$ & $\begin{array}{c}\mathrm{N}=207 \text { academically talented } \\
\text { adolescents. }\end{array}$ & Help-seeking Scale $[8,45]$. & $\begin{array}{c}\text { Help-seeking is related to achievement } \\
\text { goals. There are } 4 \text { clusters of } \\
\text { achievement goals with different AHS } \\
\text { profiles. }\end{array}$ \\
\hline $\begin{array}{l}\text { Parker, Shum, Suldo, } \\
\text { Shaunessy, Ferron, } \\
\text { and Dedrick (2019) }\end{array}$ & $\mathrm{N}=331$ adolescents. & $\begin{array}{c}\text { Attitudes towards } \\
\text { Help-seeking Scale and } \\
\text { Adaptive Help-seeking Scale } \\
\text { [15]. }\end{array}$ & $\begin{array}{l}\text { Adaptive AHS is predicted by adaptive } \\
\text { perfectionism, perceived benefits of } \\
\text { AHS, teacher emotional support, and } \\
\text { gender. }\end{array}$ \\
\hline $\begin{array}{l}\text { Smalley and } \\
\text { Hopkins (2020) }\end{array}$ & $\mathrm{N}=551$ adolescents. & Help-seeking Scale [15]. & $\begin{array}{c}\text { AHS avoidance is negatively related to } \\
\text { social climate, social self-efficacy, } \\
\text { academic self-efficacy, and theories of } \\
\text { intelligence. }\end{array}$ \\
\hline
\end{tabular}

The relationship between achievement goals and academic help-seeking has also been examined [33,36]. Both these studies found that instrumental help-seeking is positively related to mastery goals and the perceived benefits of help-seeking. On the other hand, the perceived costs of help-seeking were related to performance goals. However, Gonida et al. [36] included other variables, such as intention to seek academic help and helpseeking avoidance. Intention to seek academic help was related to mastery-approach goals, while help-seeking avoidance was positively related to performance-avoidance goals but negatively related to mastery-approach goals. The clusters formed in this study confirmed 
that students with high scores on mastery goals reported adaptive help-seeking beliefs and intentions when their scores on performance goals were low. Additionally, according to Roussel et al. [33], the perceived costs and perceived benefits of help-seeking mediated the association between instrumental help-seeking and achievement goals.

When Cheng et al. [38] studied the relationship between self-regulation strategies (basic and advanced) and help-seeking, they found that only advanced strategies were related to all forms of help-seeking included in their research (information searching, informal query and formal query) and that these strategies mediated the association between internet-specific epistemic beliefs and help-seeking. Basic self-regulated strategies, on the other hand, were associated with information searching and informal query, and had no mediating role.

An essential concern of studies of help-seeking is to examine its relationship with academic outcomes. In this regard, Kessels and Steinmayr [34] found, after controlling for prior school performance, intelligence, and masculinity, that academic outcomes could be predicted by the perceived benefits of help-seeking and instrumental help-seeking in male students. Similar results were found by Schenke et al. [31], who found an association between help-seeking from teachers and better academic outcomes in mathematics, and observed that instrumental help-seeking could predict academic outcomes. Students' interest in the subject can also be considered an outcome of the teaching process. Indeed, Butler and Shibaz [35] found an association between help-seeking and student academic interest.

In online academic help-seeking, epistemic beliefs about the knowledge available on the Internet may play an important role. When addressing this, Cheng et al. [38] found that the source of knowledge, or the belief that knowledge is transmitted by an external authority, was negatively related to information searching, formal query, and informal query. However, justification for knowing, which is more complex and sophisticated, was positively related to information searching and informal query. It was also found that only justification for knowing influenced help-seeking via the mediation of selfregulation variables. A slightly different result was found by Lee et al. [39], who used four factors to assess Internet-specific epistemic beliefs (uncertainty, complexity, self-source, and justification). Information searching was predicted positively by justification and negatively by complexity. Formal query was negatively predicted by uncertainty and complexity. Informal query, on the other hand, was negatively predicted by uncertainty, complexity, and self-source, and positively predicted by justification. Both the above studies show that this type of epistemic beliefs can indicate the type of help students seek.

Finally, several articles in this review focused on variables related to the role of the teacher and the climate and goal structure of the classroom. Classroom social climate was evaluated by Smalley and Hopkins [29], who assessed the following four factors: task orientation, investigation, cooperation, and teacher support. All these factors were negatively related to avoidance of help-seeking, which indicates that the environment teachers create in the classroom can influence this behaviour. Teacher support was positively associated with instrumental help-seeking, help-seeking from peers and, more strongly, with help-seeking from teachers, but was negatively associated with executive help-seeking [31]. Kiefer and Shim [28] replicated these results in the case of instrumental help-seeking and executive help-seeking and, like Smalley and Hopkins [29], found that teacher support was negatively associated with avoidance of help-seeking. Parker et al. [37] also found a positive relationship between teacher support and adaptive help-seeking and between teacher support and the perceived benefits of help-seeking. They also found a negative association between teacher support and the perceived costs of help-seeking.

In the study by Schenke et al. [31], the classroom goal structure was linked to helpseeking. In performance-oriented classrooms, there was more expedient help-seeking and less help-seeking from teachers than in mastery-oriented classrooms. In masteryoriented classrooms, the association was with instrumental help-seeking and help-seeking from peers. Finally, Butler and Shibaz [35] reported how teacher goals and the teacher 
instructional approach influenced students' help-seeking. However, only relational goals had a significant effect on help-seeking.

\section{Psycho-Social Variables}

When social goals such as popularity, dominance, and intimacy were studied by Kiefer and Shim [28], they found that gender plays a crucial role in moderating the relationship between social goals and academic help-seeking. For example, dominance goals had a negative relationship with adaptive help-seeking for boys but not for girls. Intimacy goals, on the other hand, were positively related to adaptive help-seeking for girls but not for boys.

A positive relationship was found between expedient (or executive) help-seeking and both dominance and popularity, while a negative relationship was found with intimacy. Gender also had a moderating effect since dominance was positively related to expedient help-seeking in boys, but negatively related to it in girls. Social goals did not influence helpseeking avoidance when regressed. Roussel et al. [33] found that friendship-approach goals positively predicted instrumental help-seeking, but negatively predicted the perceived costs of help-seeking, while friendship-avoidance goals had the opposite effects on those variables. None of the friendship goals affected the perceived benefits of help-seeking.

The role of academic self-efficacy has also been studied, but the results have been inconclusive. Kiefer and Shim [28], for example, found a negative association between executive help-seeking and academic self-efficacy, but their results on instrumental helpseeking and avoidance of help-seeking were inconclusive. Smalley and Hopkins [29], on the other hand, found negative associations between help-seeking avoidance and academic self-efficacy and between help-seeking avoidance and social self-efficacy with peers. Kiefer and Shim [28] found a negative association between social self-efficacy and adaptive help-seeking, but a positive association between social self-efficacy and avoidance of help-seeking. However, this relationship was found at only one of the two time points assessed.

Perfectionism (both adaptive and maladaptive) was studied by Parker et al. [37]. These authors reported that adaptive help-seeking was positively related to adaptive perfectionism, but negatively related to maladaptive perfectionism and that the pattern was the same for the perceived benefits of help-seeking. In contrast, perceived threats of help-seeking were positively related to maladaptive perfectionism. Intelligence and help-seeking were studied by Kessels and Steinmayr [34], but they found no significant relationship. When Smalley and Hopkins [29] studied the effect of theories of intelligence on help-seeking avoidance, they reported that an incremental theory of intelligence may be linked to lower help-seeking avoidance.

\subsubsection{Results for University Students}

Fifteen articles focused on university students, with samples ranging from 93 to 2107 participants. The variables discussed in these articles are sociodemographic (e.g., age, gender, and ethnicity), educational (e.g., achievement goals, self-regulated learning, academic, and outcome), and psychosocial (e.g., gender role norms, emotional intelligence, and locus of control). The main results for these articles are shown in Table 3.

\section{Socio-Demographic Variables}

Results in relation to the gender of the participants are inconclusive. Some articles reported more positive attitudes towards help-seeking in female students [30,46,47], while others found no gender differences [48-51].

The age of the participants was negatively related to help-seeking [48,52]. Yang et al. [48] also found that age negatively predicted help-seeking. On the other hand, Parnes et al. [30] reported no age-related differences, but did find relationships between ethnicity and help-seeking. Specifically, they found that Asian students scored higher on help- 
seeking avoidance and had a more negative perception of the usefulness of help-seeking than Black/African American, Latino/Hispanic, and White students.

\section{Educational Variables}

Two articles describe the sources of help most often used by university students. Dawson et al. [53] showed that students seek help from friends or the Internet more often than from parents or their instructor. Cheng et al. [54] also found that information searching was more common than formal or informal query and that there was a positive relationship between all types of help-seeking. According to Wimer and Levant [55], instrumental help-seeking is more common than executive help-seeking. These authors also reported a negative relationship between those variables, as well as a negative association between instrumental help-seeking and avoidance of help-seeking, and a positive association between executive help-seeking and avoidance of help-seeking. However, these results were not replicated in other studies. For instance, Xie and Xie [50] only found the negative association between instrumental help-seeking and help-seeking avoidance, and the positive association between executive help-seeking and help-seeking avoidance. Similarly, Won et al. [56] found no association between adaptive help-seeking and expedient help-seeking. Parnes et al. [30] included network orientation as a variable. This can be interpreted as help-seeking because it refers to how often students ask for help and how much this help is useful for them. Both these factors had a positive relationship with a general measure of help-seeking.

A discrepancy exists among studies that analysed the relationship between academic performance and help-seeking. For example, Bartels et al. [57] and Blondeau and Awad [51] reported no association between help-seeking and academic outcome, whereas Astatke [49] described a positive association. From another perspective, Finney et al. [58] described four types of help-seeking depending on the scores on help-seeking factors. The differences in academic achievement between these types reached significance, which indicates that further help-seeking profiles may be related to the scores obtained by students.

Table 3. Characteristics, measures, and key findings from studies on adolescent students.

\begin{tabular}{|c|c|c|c|}
\hline Author and Year & Sample & HS Measure & Results \\
\hline $\begin{array}{l}\text { Dawson, Meadows, } \\
\text { andHaffie (2010) }\end{array}$ & $\mathrm{N}=324$ university students. & $\begin{array}{l}\text { Motivated Strategies for } \\
\text { Learning Questionnaire } \\
\text { (MSLQ) [27]. }\end{array}$ & $\begin{array}{l}\text { With high self-efficacy there is a } \\
\text { relationship between } \\
\text { clicker-performance and AHS } \\
\text { resources, and between course-grades } \\
\text { and AHS resources and AHS scale. } \\
\text { Informal sources are more frequently } \\
\text { asked. }\end{array}$ \\
\hline $\begin{array}{c}\text { Bartels, } \\
\text { Magun-Jackson and } \\
\text { Ryan (2011) }\end{array}$ & $\mathrm{N}=141$ university students. & $\begin{array}{l}\text { Motivated Strategies for } \\
\text { Learning Questionnaire } \\
\text { (MSLQ) [59]. }\end{array}$ & $\begin{array}{c}\text { AHS correlated with mastery goals and } \\
\text { volition. No interference of AHS in } \\
\text { performance goals settings. }\end{array}$ \\
\hline $\begin{array}{l}\text { Wimer and Levant } \\
\text { (2011) }\end{array}$ & $\begin{array}{c}\mathrm{N}=193 \text { male university } \\
\text { students. }\end{array}$ & $\begin{array}{l}\text { Psychology Help-Seeking } \\
\text { Scale. Adapted from [60]. }\end{array}$ & $\begin{array}{l}\text { Conformity with traditional male } \\
\text { norms predicts avoidance of } \\
\text { help-seeking. }\end{array}$ \\
\hline $\begin{array}{l}\text { Cheng, Liang, andTsai } \\
\text { (2013) }\end{array}$ & $\mathrm{N}=328$ university students. & $\begin{array}{c}\text { Online Academic } \\
\text { Help-seeking questionnaire } \\
\text { (OAHS) [6]. }\end{array}$ & $\begin{array}{l}\text { OAHS scales are correlated with } \\
\text { Self-Regulated Learning variables. } \\
\text { Online students prefer to seek } \\
\text { information rather than ask questions. }\end{array}$ \\
\hline $\begin{array}{l}\text { Dunn, Rakes, and } \\
\text { Rakes (2014) }\end{array}$ & $\mathrm{N}=165$ university students. & $\begin{array}{l}\text { Motivated Strategies for } \\
\text { Learning Questionnaire } \\
\text { (MSLQ) [59]. }\end{array}$ & $\begin{array}{l}\text { Help-seeking can be predicted by } \\
\text { critical thinking, general strategies for } \\
\text { learning, and age. }\end{array}$ \\
\hline Holt (2014) & $\mathrm{N}=93$ university students. & $\begin{array}{l}\text { Attitudes about Academic } \\
\text { Help-seeking [45]. }\end{array}$ & $\begin{array}{l}\text { Attitudes towards academic } \\
\text { help-seeking are related to parental } \\
\text { attachment and gender, and can } \\
\text { influence academic adjustment. }\end{array}$ \\
\hline
\end{tabular}


Table 3. Cont.

\begin{tabular}{|c|c|c|c|}
\hline Author and Year & Sample & HS Measure & Results \\
\hline Holt (2014) & $\mathrm{N}=204$ university students. & $\begin{array}{l}\text { Attitudes about Academic } \\
\text { Help-seeking [45]. }\end{array}$ & $\begin{array}{l}\text { Help-seeking is related to female, } \\
\text { parental attachment, self-compassion, } \\
\text { social competence, and academic } \\
\text { adjustment. }\end{array}$ \\
\hline $\begin{array}{l}\text { Yang, Taylor, and Cao } \\
\text { (2016) }\end{array}$ & N = 209 university students. & $\begin{array}{l}\text { Motivated Strategies for } \\
\text { Learning Questionnaire } \\
\text { (MSLQ) [27]. }\end{array}$ & $\begin{array}{l}3 \times 2 \text { achievement goal model is } \\
\text { related to help-seeking. Help-seeking is } \\
\text { predicted by self-approach, other } \\
\text { avoidance, and self-efficacy. }\end{array}$ \\
\hline $\begin{array}{l}\text { Blondeau and Awad } \\
\qquad(2017)\end{array}$ & $\mathrm{N}=180$ university students. & Help-seeking Scale [7]. & $\begin{array}{c}\text { Gender and Help-seeking predict } \\
\text { career guidance. No differences in } \\
\text { instrumental AHS between male and } \\
\text { female students. }\end{array}$ \\
\hline Astatke (2018) & $\mathrm{N}=283$ university students. & $\begin{array}{c}\text { Academic Help-seeking } \\
\text { Behaviour Questionnaire [61]. }\end{array}$ & $\begin{array}{l}\text { Correlations between AHS and } \\
\text { Psychological HS and academic } \\
\text { achievement. No relationship between } \\
\text { AHS and emotional intelligence. }\end{array}$ \\
\hline $\begin{array}{l}\text { Finney, Barry, Horst, } \\
\text { and Johnston (2018) }\end{array}$ & $\begin{array}{l}\text { Study 1: } \mathrm{N}=1950 \text { university } \\
\text { students. } \\
\text { Study 2: } \mathrm{N}=2107 \text { university } \\
\text { students. }\end{array}$ & $\begin{array}{l}\text { General Measure of } \\
\text { Help-seeking [45]. }\end{array}$ & $\begin{array}{c}\text { Elements related with approaching } \\
\text { AHS are related in general with } \\
\text { positive academic outcomes, and } \\
\text { avoidance elements with the opposite } \\
\text { profile. There are different AHS } \\
\text { profiles. }\end{array}$ \\
\hline Xie and Xie (2019) & $\mathrm{N}=559$ university students. & $\begin{array}{l}\text { Undergraduate Academic } \\
\text { Help-seeking Scale [62]. }\end{array}$ & $\begin{array}{l}\text { Help-seeking variables are related to } \\
\text { commitment variables and academic } \\
\text { self-efficacy. Differences in gender for } \\
\text { self-efficacy related to AHS in women. }\end{array}$ \\
\hline $\begin{array}{l}\text { Won, Hensley, and } \\
\text { Wolters (2019) }\end{array}$ & $\mathrm{N}=307$ university students. & $\begin{array}{l}\text { Academic Help-seeking Scale } \\
{[43] .}\end{array}$ & $\begin{array}{l}\text { Adaptive AHS is related to sense of } \\
\text { belonging, self-efficacy for SRL and } \\
\text { utility value. Expedient AHS is } \\
\text { negatively related to utility value. }\end{array}$ \\
\hline $\begin{array}{l}\text { Micari and Calkins } \\
\text { (2019). }\end{array}$ & $\mathrm{N}=252$ university students. & $\begin{array}{l}\text { Academic Help-seeking Scale } \\
\text { [63]. }\end{array}$ & $\begin{array}{l}\text { Help-seeking is related to perceived } \\
\text { teacher support and final grades. }\end{array}$ \\
\hline $\begin{array}{l}\text { Parnes, Kanchewa, } \\
\text { Marks, and Schwartz } \\
\text { (2020) }\end{array}$ & $\mathrm{N}=396$ university students. & $\begin{array}{l}\text { Help-seeking Scale [8]. } \\
\text { Network orientation [64]. }\end{array}$ & $\begin{array}{l}\text { Differences in AHS avoidance } \\
\text { depending on ethnicity. AHS } \\
\text { avoidance is related to network } \\
\text { orientation variables. }\end{array}$ \\
\hline
\end{tabular}

Cheng et al. [54] reported a positive relationship between self-regulated learning and help-seeking. More precisely, they found a significant association between basic self-regulated learning and information searching and formal query, and a stronger and significant association between advanced self-regulated learning and information searching, formal query and informal query. Moreover, basic self-regulated learning predicted information searching, while advanced self-regulated learning did so with formal query. Dunn et al. [52] found a positive association between help-seeking and general self-regulation as well as a positive association of the same magnitude between critical thinking and help-seeking.

Achievement goals were studied in three articles in our review. Bartels et al. [57] found a significant relationship between mastery-approach goals and help-seeking but no relationship with performance-approach goals. It is worth noting that neither masteryavoidance nor performance-avoidance were included in their study. These authors created four groups and combined high and low mastery-approach and performance-approach, but found no differences related to academic help-seeking. However, they did report differences in volitional strategies, which was positively associated with help-seeking. 
Finney et al. [58] proposed four types of help-seeking profiles and observed significant differences in achievement goals among them. Yang et al. [48] found that self-approach and other-avoidance positively predicted help-seeking and self-avoidance, and that otherapproach negatively predicted help-seeking.

Professional commitment can be applied to university students, as Xie and Xie [50] demonstrated. Professional commitment measures students' attitudes and behaviours using four factors: affective commitment, continuance commitment, normative commitment, and ideal commitment. All these dimensions were positively associated with instrumental help-seeking and negatively associated with the avoidance of help-seeking, while only affective commitment and ideal commitment were negatively associated with executive help-seeking. The above authors also found that affective commitment mediated the association between academic self-efficacy and help-seeking. When Won et al. [56] analysed the role of sense of belonging, they found a positive relationship with adaptive help-seeking, but no relationship with expedient help-seeking. However, being part of an underrepresented minority, studying at a regional campus, and being a transfer student were negative predictors of sense of belonging, which predicted adaptive help-seeking. Similarly, Parnes et al. [30] found that the first generation of university students, i.e., students whose parents had not attended college, were less likely to consider it useful to ask others for help or to search for help.

College adjustment was studied in two articles by Holt in the context of parental attachment. In the first of these articles [46], attitudes about academic help-seeking mediated how parental attachment and gender relate to academic adjustment. In the second [47], college adjustment was measured using three dimensions (academic, personal/emotional, and social), all of which had a positive relationship with help-seeking. The results of the former study on the mediating role of help-seeking were replicated in the latter.

According to Blondeau and Awad [51], career guidance from instructors was positively related to instrumental help-seeking, but only for female students. Student gender and instrumental help-seeking were therefore both predictors of career guidance. Moreover, the effect of student gender depended on the gender of the instructor. When it comes to help-seeking, the instructor can be an important factor. Micari and Calkins [32], for example, found an association between instructor openness and help-seeking. In addition, when they measured help-seeking at the beginning and end of the academic term, they found that help-seeking at the beginning together with instructor openness predicted helpseeking at the end. A small but significant indirect effect was also found for help-seeking mediating the association between instructor openness and academic outcome. Parnes et al. [30] found an association between instructor relationships and help-seeking.

Finally, Won et al. [56] found that utility value was positively associated with adaptive help-seeking, but negatively associated with expedient help-seeking. Moreover, utility value also predicted expedient help-seeking, so when the task was perceived as more relevant, there was less expedient help-seeking.

\section{Psycho-Social Variables}

Dawson et al. [53] found no relationship between help-seeking and internal or external locus of control. Similarly, Astatke [49] found no association between emotional intelligence and help-seeking. As we mentioned earlier, Finney et al. [58] found significant differences among four types of help-seeking profiles in variables such as theories of intelligence and motivation. Self-compassion and social competence, with similar positive correlation values, were linked to help-seeking by Holt [47].

Several studies in our review evaluated self-efficacy in the academic context. Dawson et al. [53], for example, studied the use of clickers (devices that enable students to answer questions and get feedback in real-time) and found that self-efficacy mediated the relationship between help-seeking and clicker performance. For instance, when the students had low self-efficacy, there was no relationship between those variables, but when they had high self-efficacy, the relationship was positive. The same effect was found for help-seeking 
and academic outcome with the moderation of self-efficacy. Additionally, participants with high self-efficacy reported seeking more help from their instructor. According to Xie and Xie [50], academic self-efficacy was positively related to instrumental help-seeking and negatively related to both executive help-seeking and help-seeking avoidance. More precisely, the negative association between self-efficacy and executive help-seeking was significant among women, but not among men. Won et al. [56] assessed self-efficacy for self-regulated learning, i.e., the confidence students have when implementing self-regulation skills. This type of self-efficacy was also related to adaptive help-seeking, but had no association with expedient help-seeking.

Traditional masculinity was studied in a sample of all-male university students by Wimer and Levant [55], who reported a positive relationship with help-seeking avoidance but not with executive or instrumental help-seeking. In relation to conformity to masculine norms, help-seeking avoidance and executive help-seeking were positively related to total score while instrumental help-seeking was negatively related. Conformity to masculine norms also predicted help-seeking avoidance, as did dominance and self-reliance.

Help-seeking can be useful in multiple contexts. As well as in the academic context, for example, it can be useful when it comes to psychological problems. Astatke [49] found a positive relationship between these two help-seeking applications.

\section{Discussion}

The aims of this review were to better understand the role of help-seeking as a learning strategy in adolescent and university students, describe the relationships that have been found with other variables, and evaluate the most common instruments used to assess it. We have reviewed 25 articles on help-seeking in adolescent and university students published between 2010 and 2020, and detected certain tendencies. First, there is a lack of consensus on the structure of help-seeking as a construct, the number of its components, and the relationship between those components. This could be why there is a proliferation of tests intended to measure it. We should also bear in mind that, since research on helpseeking is recent, greater knowledge of this topic may make it necessary to renew current measures.

In adolescents, two groups of help-seeking variables or components are proposed according to whether they are adaptive for students. For example, instrumental helpseeking, the perceived benefits of help-seeking, intention to seek help, help-seeking from peers, and help-seeking from teachers may be considered adaptive and generally show a positive relationship with each other. The other group comprises avoidance of help-seeking, expedient help-seeking, and the perceived costs of help-seeking, which show a positive relationship with each other, but are negatively related to the variables we have called adaptive. In university students, we find the same pattern, though not all studies found the same relationships.

There is no agreement on gender or age differences among studies of adolescents or university students. Further research is needed to establish whether these factors play a role and, if so, in what circumstances.

The variables seldom appear more than once in our review. This may be because of the need to make an original contribution to the field or due to the replication crisis in the psychology field $[65,66]$. However, some variables between adolescents and university students can be compared. Achievement goals, for example, have been studied in both groups, though help-seeking has been measured differently and comparisons are difficult to make. In any case, the goals that may be considered more adaptive (such as mastery goals) are related to more adaptive help-seeking (such as instrumental help-seeking or intention to seek help).

Self-efficacy has also been studied in both populations, but the results are inconclusive for adolescents. For university students, however, self-efficacy was proposed as a mediating factor between help-seeking and academic outcome. It was also positively related to instrumental help-seeking, but negatively related to help-seeking avoidance. This may 
mean that self-efficacy has a differential effect depending on age or study level that makes it more related to help-seeking at university than at an earlier academic stage. It would be interesting if further research could address this issue and find an explanation.

Results indicate that there is a relationship between self-regulation and help-seeking. This is particularly relevant when it is addressed as self-regulated learning since the literature considers help-seeking a strategy within this construct [1]. Moreover, this relationship was stronger when the students' strategies were more advanced.

Differences also arise in our conclusions regarding academic outcome. For adolescents, academic outcome is positively related to instrumental help-seeking and the perceived benefits of help-seeking. For university students, on the other hand, there are discrepancies in the results. This may be explained by the different nature of the contexts in which the learning takes place such that for university students other factors may mediate the relationship between help-seeking and academic outcome.

\section{Conclusions}

Academic production over the past ten years has explored a wide range of variables that affect help-seeking. However, further research is needed in order to better define the construct and enable a better comparison between studies. It is also important to clarify the relationships between certain important educational variables and academic help-seeking, explain the differences between different contexts and educational stages, and take into account the dispositional variables that can affect the results. Different educational professionals can use this information, such as teachers, educational psychologists, educational counsellors, and teacher leaders. Data has shown that AHS is a variable to consider in guiding students toward academic success and retaining students in the educational system. According to the data reported by the articles included in the review, different sociodemographic variables such as age or gender may influence AHS strategies; however, there is no consensus in the literature, so future studies are necessary to establish whether these factors play a role. As there is a lack of consensus on the structure of the AHS as a construct and the number of its components, future studies should focus on verifying the psychometric properties of these tests in different cultures, as it would help to systematize the findings and clarify its factors. The AHS field of study is still largely unexplored, so this study will open new research opportunities within the educational sciences.

Author Contributions: The research was designed and performed by S.M.-A., E.C. and J.-M.D. The first author (S.M.-A.) has collected the data and wrote most of the manuscript. E.C. and J.M.D. supervised the work and revised the manuscript. All authors collaborated and agreed to the published version of the manuscript.

Funding: This research received no external funding.

Institutional Review Board Statement: Not applicable.

Informed Consent Statement: Not applicable.

Data Availability Statement: Not applicable.

Conflicts of Interest: The authors declare no conflict of interest.

\section{References}

1. Karabenick, S.A.; Berger, J. Help seeking as a self-regulated learning strategy. In Applications of Self-Regulated Learning across Diverse Disciplines. A Tribute to Barry J. Zimmerman; IAP Information Age Publishing: Carlotte, NC, USA, 2013 ; pp. $237-261$.

2. Nelson-Le Gall, S. Help-Seeking: An understudied skill in children. Dev. Rev. 1981, 1, 224-246. [CrossRef]

3. Zimmerman, B.J. Investigation self-regulation and motivation: Historical background, methodological developments, and futur prospects. Am. Educ. Res. J. 2008, 45, 166-183. [CrossRef]

4. Newman, R.S. Children's help-seeking in the classroom: The role of motivational factors and attitudes. J. Educ. Psychol. 1990, 82, 71-80. [CrossRef]

5. Ryan, A.M.; Shin, H. Help-Seeking tendencies during early adolescence: An examination of motivational correlates and consequences for achievement. Learn. Instr. 2011, 21, 247-256. [CrossRef] 
6. Cheng, K.-H.; Tsai, C.-C. An investigation of Taiwan University students' perceptions of online academic help seeking, and their web-based learning self-efficacy. Internet High. Educ. 2011, 14, 150-157. [CrossRef]

7. Karabenick, S.A.; Knapp, J.R. Relationship of academic help seeking to the use of learning strategies and other instrumental achievement behavior in college students. J. Educ. Psychol. 1991, 83, 221-230. [CrossRef]

8. Karabenick, S.A. Perceived achievement goal structure and college student help seeking. J. Educ. Psychol. 2004, 96, 569-581. [CrossRef]

9. Butler, R. Determinants of help seeking: Relations between perceived reasons for classroom help-avoidance and help-seeking behaviors in an experimental context. J. Educ. Psychol. 1998, 90, 630-643. [CrossRef]

10. Puustinen, M.; Rouet, J.F. Learning with new technologies: Help seeking and information searching revisited. Comput. Educ. 2009, 53, 1014-1019. [CrossRef]

11. Zimmerman, B.J. From cognitive modeling to self-regulation: A social cognitive career path. Educ. Psychol. 2013, 48, 135-147. [CrossRef]

12. Gross, A.E.; McMullen, P.A. Models of the help-seeking process. In New Directions in Helping: Help-Seeking; DePaulo, B.M., Nadler, A., Fisher, J.D., Eds.; Academic Press: New York, NY, USA, 1983; Volume 2, pp. 47-70.

13. Karabenick, S.A.; Newman, R.S. Seeking help: Generalizable self-regulatory process and social-cultural barometer. In Contemporary Motivation Research: From Global to Local Perspectives; Wosnitza, M., Karabenick, S.A., Efklides, A., Nenniger, P., Eds.; Hogrefe \& Huber Publishers: Boston, MA, USA, 2009; pp. 25-48.

14. Zimmerman, B.J. Attaining self-regulation: A social cognitive perspective. In Handbook of Self-Regulation; Boekaerts, M., Pintrich, P.R., Zeidner, M., Eds.; Academic Press: Cambridge, MA, USA, 2000; pp. 13-39.

15. Ryan, A.M.; Pintrich, P.R. Should I ask for help? The role of motivation and attitudes in adolescents' Help seeking in math class. J. Educ. Psychol. 1997, 89, 329-341. [CrossRef]

16. Marchand, G.; Skinner, E.A. Motivational dynamics of children's academic help-seeking and concealment. J. Educ. Psychol. 2007, 99, 65-82. [CrossRef]

17. Newman, R.S. How self-regulated learners cope with academic difficultry: The role of adaptive help seeking. Theory Pract. 2002, 41, 132-138. [CrossRef]

18. Nelson-Le Gall, S. Help-Seeking behavior in learning. Rev. Res. Educ. 1985, 12, 55-90. [CrossRef]

19. Ryan, A.M.; Patrick, H.; Shim, S. Differential profiles of students identified by their teacher as having avoidant, appropriate, or dependent help-seeking tendencies in the classroom. J. Educ. Psychol. 2005, 97, 275-285. [CrossRef]

20. Cheong, Y.F.; Pajares, F.; Oberman, P.S. Motivation and academic help-seeking in high school computer science. Comput. Sci. Educ. 2004, 14, 3-19. [CrossRef]

21. Qayyum, A. Student help-seeking attitudes and behaviors in a digital era. Int. J. Educ. Technol. High. Educ. 2018, 15. [CrossRef]

22. Black, S.; Allen, J.D. Part 8: Academic help seeking. Ref. Libr. 2019, 60, 62-76. [CrossRef]

23. Moher, D.; Liberati, A.; Tetzlaff, J.; Altman, D.G.; Altman, D.; Antes, G.; Atkins, D.; Barbour, V.; Barrowman, N.; Berlin, J.A.; et al. Preferred reporting items for systematic reviews and meta-analyses: The PRISMA statement. PLoS Med. 2009,6 , e1000097. [CrossRef]

24. Liberati, A.; Altman, D.G.; Tetzlaff, J.; Mulrow, C.; Gøtzsche, P.C.; Ioannidis, J.P.A.; Clarke, M.; Devereaux, P.J.; Kleijnen, J.; Moher, D. The PRISMA statement for reporting systematic reviews and meta-analyses of studies that evaluate health care interventions: Explanation and elaboration. PLoS Med. 2009, 6, e1000100. [CrossRef]

25. Caldwell, K.; Henshaw, L.; Taylor, G. Developing a framework for critiquing health research. J. Health Soc. Environ. Issues 2005, 6, 45-54.

26. Surr, C.A.; Gates, C.; Irving, D.; Oyebode, J.; Smith, S.J.; Parveen, S.; Drury, M.; Dennison, A. Effective dementia education and training for the health and social care workforce: A systematic review of the literature. Rev. Educ. Res. 2017, 87, 966-1002. [CrossRef] [PubMed]

27. Pintrich, P.R.; Smith, D.A.F.; Garcia, T.; McKeachie, W.J. Reliability and predictive validity of the Motivated Strategies for Learning Questionnaire (MSLQ). Educ. Psychol. Meas. 1993, 53, 801-813. [CrossRef]

28. Kiefer, S.M.; Shim, S.S. Academic help seeking from peers during adolescence: The role of social goals. J. Appl. Dev. Psychol. 2016, 42, 80-88. [CrossRef]

29. Smalley, R.T.; Hopkins, S. Social Climate and Help-Seeking Avoidance in Secondary Mathematics Classes; Springer: Dordrecht, The Netherlands, 2020; Volume 47, ISBN 0123456789.

30. Parnes, M.F.; Kanchewa, S.S.; Marks, A.K.; Schwartz, S.E.O. Closing the college achievement gap: Impacts and processes of a help-seeking intervention. J. Appl. Dev. Psychol. 2020, 67, 101121. [CrossRef]

31. Schenke, K.; Lam, A.C.; Conley, A.M.M.; Karabenick, S.A. Adolescents' help seeking in mathematics classrooms: Relations between achievement and perceived classroom environmental influences over one school year. Contemp. Educ. Psychol. 2015, 41, 133-146. [CrossRef]

32. Micari, M.; Calkins, S. Is it OK to ask? The impact of instructor openness to questions on student help-seeking and academic outcomes. Act. Learn. High. Educ. 2019. [CrossRef]

33. Roussel, P.; Elliot, A.J.; Feltman, R. The influence of achievement goals and social goals on help-seeking from peers in an academic context. Learn. Instr. 2011, 21, 394-402. [CrossRef] 
34. Kessels, U.; Steinmayr, R. Macho-Man in school: Toward the role of gender role self-concepts and help seeking in school performance. Learn. Individ. Differ. 2013, 23, 234-240. [CrossRef]

35. Butler, R.; Shibaz, L. Striving to connect and striving to learn: Influences of relational and mastery goals for teaching on teacher behaviors and student interest and help seeking. Int. J. Educ. Res. 2014, 65, 41-53. [CrossRef]

36. Gonida, E.N.; Karabenick, S.A.; Stamovlasis, D.; Metallidou, P. CTY Greece help seeking as a self-regulated learning strategy and achievement goals: The case of academically talented adolescents. High Abil. Stud. 2019, 30, 147-166. [CrossRef]

37. Parker, J.S.; Shum, K.Z.; Suldo, S.M.; Shaunessy-Dedrick, E.; Ferron, J.M.; Dedrick, R.F. Predictors of adaptive help seeking across ninth-grade students enrolled in advanced placement and international baccalaureate courses. Psychol. Sch. 2019, 56, 652-669. [CrossRef]

38. Cheng, K.-H.; Liang, J.-C.; Tsai, C.-C. The role of internet-specific epistemic beliefs and self-regulation in high school students' online academic help seeking: A structural equation modeling analysis. J. Educ. Comput. Res. 2013, 48, 469-489. [CrossRef]

39. Lee, W.C.; Chiu, Y.L.; Liang, J.C.; Tsai, C.C. Exploring the structural relationships between high school students' internet-specific epistemic beliefs and their utilization of online academic help seeking. Comput. Hum. Behav. 2014, 36, 391-400. [CrossRef]

40. Wolters, C.A.; Pintrich, P.R.; Karabenick, S.A. Assessing self-regulated learning. In Proceedings of the Conference on Indicators of Positive Development: Definitions, Measures, and Prospective Validity, Washington, DC, USA, 12-13 March 2003.

41. Butler, R. Ego-Involving and frame of reference effects of tracking on elementary school students' motivational orientations and help seeking in math class. Soc. Psychol. Educ. 2008, 11, 5-23. [CrossRef]

42. Ryan, A.M.; Hicks, L.; Midgley, C. Social goals, academic goals, and avoiding seeking help in the classroom. J. Early Adolesc. 1997, 17, 152-171. [CrossRef]

43. Ryan, A.M.; Shim, S.S. Changes in help seeking from peers during early adolescence: Associations with changes in achievement and perceptions of teachers. J. Educ. Psychol. 2012, 104, 1122-1134. [CrossRef]

44. Ryan, A.M.; Shim, S.S.; Lampkins-Uthando, S.A.; Kiefer, S.M.; Geneene, N.T. Do gender differences in help avoidance vary by ethnicity? An examination of African American and European American students during early adolescence. Dev. Psychol. 2009, 45, 1152-1163. [CrossRef]

45. Karabenick, S.A. Seeking help in large college classes: A person-centered approach. Contemp. Educ. Psychol. 2003, 28, 37-58. [CrossRef]

46. Holt, L.J. Attitudes about help-seeking mediate the relation between parent attachment and academic adjustment in first-year college students. J. Coll. Stud. Dev. 2014, 55, 418-423. [CrossRef]

47. Holt, L.J. Help seeking and social competence mediate the parental attachment—College student adjustment relation. Pers. Relatsh. 2014, 21, 640-654. [CrossRef]

48. Yang, Y.; Taylor, J.; Cao, L. The $3 \times 2$ Achievement goal model in predicting online student test anxiety and help-seeking. Electron. J. eLearn. 2016, 32, 1-16.

49. Astatke, M. First-Year college students' emotional intelligence and help-seeking behaviours as correlates of their academic achievement. J. Stud. Aff. Afr. 2018, 6, 29-50. [CrossRef]

50. Xie, D.; Xie, Z. Effects of undergraduates' academic self-efficacy on their academic help-seeking behaviors: The mediating effect of professional commitment and the moderating effect of gender. J. Coll. Stud. Dev. 2019, 60, 365-371. [CrossRef]

51. Blondeau, L.; Awad, G. Sex differences in career guidance of undergraduate math students and the relation to help-seeking behaviors. J. Career Dev. 2017, 44, 174-187. [CrossRef]

52. Dunn, K.E.; Rakes, G.C.; Rakes, T.A. Influence of academic self-regulation, critical thinking, and age on online graduate students' academic help-seeking. Distance Educ. 2014, 35, 75-89. [CrossRef]

53. Dawson, D.L.; Meadows, K.N.; Haffie, T. The effect of performance feedback on student help-seeking and learning strategy use: Do clickers make a difference? Can. J. Scholarsh. Teach. Learn. 2010, 1. [CrossRef]

54. Cheng, K.-H.; Liang, J.-C.; Tsai, C.-C. University students' online academic help seeking: The role of self-regulation and information commitments. Internet High. Educ. 2013, 16, 70-77. [CrossRef]

55. Wimer, D.J.; Levant, R.F. The relation of masculinity and help-seeking style with the academic help-seeking behavior of college men. J. Mens Stud. 2011, 19, 256-274. [CrossRef]

56. Won, S.; Hensley, L.C.; Wolters, C.A. Brief research report: Sense of belonging and academic help-seeking as self-regulated learning. J. Exp. Educ. 2019, 89, 112-124. [CrossRef]

57. Bartels, J.M.; Magun-Jackson, S.; Ryan, J.J. Achievement goals, volitional regulation and help-seeking among college students: A multiple goal analysis. Individ. Differ. Res. 2011, 9, 41-51.

58. Finney, S.J.; Barry, C.L.; Horst, S.J.; Johnston, M.M. Exploring profiles of academic help seeking: A mixture modeling approach. Learn. Individ. Differ. 2018, 61, 158-171. [CrossRef]

59. Pintrich, P.R.; Smith, D.A.F.; Garcia, T.; McKeachie, W.J. A Manual for the Use of the Motivated Strategies for Learning Questionnaire (MSLQ); National Center for Research to Improve Postsecondary Teaching and Learning: Ann Arbor, MI, USA, 1991.

60. Pajares, F.; Cheong, Y.F.; Oberman, P. Psychometric analysis of computer science help-seeking scales. Educ. Psychol. Meas. 2004, 64, 496-513. [CrossRef]

61. Sager, J.C. The Relationship between Academic and Psychological Help Seeking and Attachment Styles. Bachelor's Thesis, Trinity College, Hartford, CT, USA, 2015. 
62. Li, X.; Cheung, P.X. Academic help-seeking: Its relation to self-efficacy, value, classroom context and academic achievement. Acta Psychol. Sin. 1999, 31, 435-443.

63. Skaalvik, S.; Skaalvik, E.M. Self-Concept, motivational orientation, and help-seeking behavior in mathematics: A study of adults returning to high school. Soc. Psychol. Educ. 2005, 8, 285-302. [CrossRef]

64. Vaux, A.; Burda, P.; Stewart, D. Orientation toward utilization of support resources. J. Community Psychol. 1986, 14, 159-170. [CrossRef]

65. Open Science Collaboration. Estimating the reproducibility of psychological science. Science 2015, 349. [CrossRef]

66. Diener, E.; Biswass-Diener, R. The Replication Crisis in Psychology. Available online: http:/ / noba.to/q4cvydeh (accessed on 1 December 2020). 